University of South Carolina

Scholar Commons

\title{
"A man in a painted garment:" The social functions of jesting in Elizabethan rhetoric and courtesy manuals
}

Christopher Holcomb

University of South Carolina - Columbia

Follow this and additional works at: https://scholarcommons.sc.edu/engl_facpub

Part of the English Language and Literature Commons

\section{Publication Info}

Published in Humor: International Journal of Humor Research, Volume 13, Issue 4, 2000, pages 429-455. Holcomb, C. (2000). "A man in a painted garment": The social functions of jesting in Elizabethan rhetoric and courtesy manuals. Humor: International Journal of Humor Research, 13(4), 429-455. DOI: 10.1515/ humr.2000.13.4.429

(C) 2000 Walter de Gruyter.

This Article is brought to you by the English Language and Literatures, Department of at Scholar Commons. It has been accepted for inclusion in Faculty Publications by an authorized administrator of Scholar Commons. For more information, please contact digres@mailbox.sc.edu. 


\section{"A man in a painted garment": The social functions of jesting in Elizabethan rhetoric and courtesy manuals}

CHRIS HOLCOMB

Abstract

Many Elizabethan rhetoric and courtesy manuals offer jesting as a powerful rhetorical strategy for managing specific situations. Although highly pragmatic, the manuals' treatments of the subject imply a sociology of humor that classifies jests according to the broader social functions they serve: jests which preserve existing social relations and jests which disrupt, or even challenge, them. What eludes this classificatory scheme, however, are the properties of jesting itself. Jesting is always a flirtation with disorder and often serves conservative and disruptive functions simultaneously. If this is so, then the manuals' discussions of jesting replay (and magnify) ambiguities and anxieties characteristic of Elizabethan culture and Elizabethan rhetorical and courtesy theory in general.

A jest appears in Tales and Quick Answers (1535?) in which an "uplandish man nourished [i.e., reared] in the woods" comes to the city and witnesses a royal procession. When he enters the city, he sees the streets filled with people shouting, "The king cometh!" The excitement of the crowd piques the bumpkin's interest, and he waits for the king's arrival. When the king does come into view with "many nobles and 'sates before him," the crowd shouts, "God save the king! God save the king!" The bumpkin, however, cannot identify the king and asks someone to point him out. A person standing nearby says to the rustic, "Yonder is he [the king] that rideth upon the goodly white horse." The bumpkin cannot believe that the man on the horse is the king, suspects that this other fellow is playing a prank on him, and delivers what turns out to be the jest's punch-line: "Is that the king? ... What thou mockest me ... Methink that is a man in a painted 
garment." This jest ends, as so many do in this jest book, with a short didactic tag that makes explicit the lesson the jest supposedly illustrates. In this case, the tag reads, "By this tale ye may perceive ... that nourishing, good bringing up and exercise been more apt to lead folk to humanity and the doing of honest things than Nature herself. Those ... are noble, free and virtuous which in their youth hath been well nourished up and virtuously endoctrined" (Zall 1963: 274). According to this tag, then, the object of laughter is the bumpkin whose country-bred ignorance prevents him from being able to identify the king and from knowing how to behave in his presence. The function of this jest, again according to the tag, is conservative. Not only does it represent correct, as opposed to incorrect, behavior and attitudes towards the sovereign, but it also clarifies and reinforces boundaries between city dwellers and rustics, that is, between the social and geographic center and the social and geographic margins.

However, one wonders: does the tag make explicit the jest's didactic content, or does it impose a particular interpretation on the events related in the anecdote an interpretation that tries to neutralize the subversive energy of the bumpkin's remark about the king? For it seems this jest is open to another interpretation, one in which the bumpkin's remark is read, not as ignorance, but as unadulterated wisdom that demystifies the king's power and the symbols used to constitute it. The bumpkin's inability to recognize the king, despite the train of "many nobles and 'astates" riding before him, the "goodly white horse," the "garment," and the shouts of the crowd, suggests the king's authority is not natural; it is not self-evident so that anybody would be able to recognize it. Instead, it is a rhetorical construct constituted by the symbols the king attaches to himself and his subjects' ability to interpret those symbols. Indeed, the king could be taken as embodying rhetoric itself since his "painted garment" may trigger associations with rhetoric as a "painted" art. Following this alternative interpretation, we laugh, not at the ignorance of the bumpkin, but at the foolishness of the people who make such a fuss over a "man in a painted garment" and perhaps at the king himself who, as the word "painted" also suggests, appears like a fool in motley.

As this anecdote, the didactic tag, and my alternative interpretation suggest, a single jest can support multiple, often contradictory interpretations and thus could serve equally contradictory functions. That it can do so derives from the nature of joking itself. As many have claimed 
jokes secure their effects by combining incongruous realms of experience in fittingly unfitting combinations. They are thus inherently ambiguous and resist efforts to stabilize their meaning and effects. ${ }^{1}$ In practice, of course, people do attribute meanings to jokes; if they didn't, then jokes would lose much, if not all, of their rhetorical efficacy. Still, there is no guarantee what meaning, or meanings, they will attribute. Consider the bumpkin jest again. It is an instance of "canned," as opposed to a "spontaneous," humor: it is relatively self-contained and can be reproduced in a variety of settings without an elaborate reconstruction of the situation in which it supposedly first occurred (Fry 1963: 44; Mulkay 1988: 57-66; Norrick 1993: 14-15). However with each new setting in which it is re-told, a new (and always complex) set of relationships come into play among the jest-teller, the listeners, and even the characters within the jest. A speaker's attitudes towards his listeners, their attitudes toward him, and both the speaker's and listeners' attitudes toward bumpkins, city-dwellers, kings, and painted garments, although they may overlap, may also diverge or even clash. ${ }^{2}$ Lines of solidarity, contention, and indifference among the participants in a jesting exchange will always impinge on who laughs at what, or if they laugh at all (English 1994: 10-14).

The instability of jesting is further complicated by the fact that jests do not emerge in vacuo. They do not issue from some transhistorical comic essence (English 1994: 8). Rather, they reproduce and produce ambiguities and contradictions in the culture in which they occur. ${ }^{3}$ Although I described the bumpkin jest as "relatively self-contained," it is nevertheless deeply embedded in, and gains resonance from, its context of production. It plays upon an ambiguity between the king's identity being natural and self-evident and its being artificial and constructed, and this ambiguity points to and participates in a broader cultural ambiguity over social identity in general. The official ideology of Tudor England rested on the notion of a God-given, natural, and unchanging social hierarchy: one's identity was fixed at birth, and one's civil, even moral, obligation was to stay put and submit to one's betters. However, this ideology was seriously challenged in the sixteenth century when England experienced dramatic increases in both social and geographic mobility. ${ }^{4}$ Relocation, in terms of both social status and region, occurred with increasing frequency during the period. As a consequence, the determinants of social identity at all levels of society became increasingly ambiguous. Is identity ascribed at birth and hence natural and absolute? 
Or is it manufactured, something that can be achieved through self-fashioning? ${ }^{5}$

The bumpkin jest dramatizes both types of mobility and some of the ambiguities that may ensue. The bumpkin, having come from an "uplandish" region, is geographically mobile. When he enters the city, stands among its citizens, and witnesses the royal procession, his mere presence is a source of ambiguity. $\mathrm{He}$ is part of the crowd of citizen onlookers, yet he is still an outsider. When he delivers his demystifying comment, he becomes an even more active source of ambiguity, confusing what is supposed to be a royal procession with what he thinks is a rather silly exhibition of a "man in a painted garment." According to the tag, it is his "uplandish" breeding that leads to this confusion. The bumpkin jest also dramatizes social mobility, although in a less direct fashion. While no character in the jest is actually socially mobile, the bumpkin's remark allows for the possibility of fashioning an elite identity by assuming the signs and trappings of nobility. Even the didactic tag, albeit unwittingly, allows for this possibility. As we have already seen, the tag suggests the bumpkin is an object of laughter because he fails to recognize the natural identity of the king. But while suggesting this, the tag undermines the notion of natural identity, for it allows anyone, through "nourishing, good bringing up" and "virtuous indoctrination," to acquire "noble, free and virtuous" qualities and thus improve on "Nature herself" In a roundabout way, then, the tag makes the same potentially disruptive point as the bumpkin's demystifying remark: namely, identity is an artificial construct that can be achieved through nurture and education.

I begin with this jest (and its rather lengthy explication) because, it illustrates many of the issues, anxieties, and difficulties found in discussions of jesting in Elizabethan rhetoric and courtesy manuals. Despite the inherent instability of jests, many of these manuals sought to codify, and thus stabilize, the practice of jesting, to reduce it to a set of teachable prescriptions. Their treatments of the subject are highly pragmatic, and they pay considerable attention to what a speaker can accomplish through jesting in specific situations: for instance, how he can use jesting to enhance his own ethos, secure the good will and attention of his listeners, and shame or humiliate an opponent or enemy. However, running across and through all of this practical advice is a sort of sociology of humor that classifies jests and jesting behavior according to the broader social functions they serve. As the manuals see it, jesting is 
a powerful resource for defending the status quo and preserving social relations already in place prior to a jesting exchange - particularly those relations threatened by increases in mobility during the period. But the manuals also recognize, if only implicitly, the disruptive energies of jesting and laughter, how they can be used not to sustain existing social relations, but to redefine, or even challenge, them. According to the manuals, these two possibilities are mutually exclusive: a jest is either socially conservative or socially disruptive. And the manuals want to keep it this way. For one, this distinction aids instruction: its ostensible intent is to mark a relatively clear boundary between those forms of jesting which orators and courtiers are permitted, even encouraged, to use and those which should be scrupulously avoided. For another, decorum requires orators and courtiers to inscribe in their every utterance the hierarchical relationships that obtain among participants in any given rhetorical exchange. The manuals' insistence that speakers' jests be socially conservative is merely an extension of this more general rule.

However, what this "calculus of effects" ignores are the properties of joking itself. ${ }^{6}$ A given jest is always open to multiple, potentially conflicting interpretations and thus can serve socially conservative and socially disruptive functions simultaneously. Even the conservative reading of the bumpkin jest hinges upon its audience perceiving the bumpkin's remark as being in some way out of line, a threat of some kind that must be discredited with laughter. It is this disturbing property of jesting - its capacity to cut both ways simultaneously - that writers of rhetoric and courtesy manuals fail to account for in their theoretical statements about the social functions of jesting. As we shall see, however, this property is frequently evident in the sample jests they use to illustrate those statements - sample jests which amply reveal that joking is always a flirtation with disorder.

\section{The place of jesting in Elizabethan rhetoric and courtesy manuals}

In order to situate the handbooks' discussions of jesting within the larger framework of Elizabethan rhetorical and courtesy theory in general, we need to begin with a relatively simple observation about the structure and function of early modern jests. Jests of the period typically dramatize encounters between people of divergent social origins, and in doing so, they play on the anxieties and tensions that almost invariably occur when different kinds of people occupy the same social space. Like "the comedy 


\section{C. Holcomb}

of the London stage," says Thomas' early modern jests frequently dramatize "the meeting of divergent customs and unequal knowledge, as town dweller collided with peasant, noble with plebeian, clerk with layman" (Thomas 1977: 77). Mangam makes a similar observation, claiming that the situations dramatized in these jests usually involve encounters "between country folk and townsfolk; between English people and foreigners, between ordinary honest folk and the learned scholar or clergyman, between men and women" (Mangam 1996: 26). A cursory glance at almost any jest book of the period will bear out these claims. There are numerous jests about servants and masters, farmers and friars, Welshmen and English knights, wives and husbands, carters and yeomen, and, as we have seen, bumpkins and kings.

Although this observation about early modern jests is relatively easy to come by, it is highly suggestive. Thomas uses it to establish a connection between the dramatic structure of jests and their contexts of production. Using Tudor and Stuart jest books as his primary source, Thomas argues that jests of the period point to "joking situations, areas of structural ambiguity in society itself, as such, they not only "reveal the social tensions of the time," but also offer strategies for dealing with them (Thomas 1977: 77). For instance, jests about husbands and supposedly unruly wives "were a means of confronting the anomalies of insubordinate female behavior which constantly threatened the working of what was supposed to be a male-dominated marital system" (Thomas 1977: 77). Thomas goes on to explore other connections between the subject matter of early modern jests and the broader social scene. However, what he fails to note is that the jest book is in many ways a Renaissance phenomenon and that its appearance coincides with dramatic increases in social and geographic mobility. In other words, encounters similar to those portrayed in jests of the period were happening with greater frequency in everyday life. Viewed in this expanded context, jests dramatizing meetings between people of divergent social origins can be seen as a response to these, oftentimes seismic, changes in social relations, a way to manage the anxieties, ambiguities, and contradictions resulting from different kinds of people living in relatively close proximity.

Thomas' and Mangam's observations are suggestive for another reason. If jests of the period typically dramatize encounters between different kinds of people, can we then say that any meeting between people of different orders of being is inherently, or at least potentially, funny, that such an encounter is a jest waiting to happen? If humor issues from the 
perception of some form of incongruity, then a meeting between different kinds of people, which is in many ways an incongruous encounter, has all the ingredients of a jest, even if no jesting takes place. Or if we place ourselves inside a jest, within the situation dramatized, can we say that jesting is not only an available strategy for communicating across social boundaries but also a particularly powerful one? Some forms of humor, particularly humor that is derisive in nature, can be used to maintain distinctions that may be blurred or elided when different kinds of people are thrown together. Speakers who deride (that is, laugh down and at) certain kinds of people assert not only their difference from but also their superiority to the objects of their laughter. Other forms of humor may be used, not to preserve social difference, but to transcend it. With a wellplaced jest, speakers may cause their social others to laugh - that is, to share, if only temporarily, the same comic perspective. In modem parlance, we call this "getting the jest," and its desired effect we call "breaking the ice."

Elizabethan rhetoric and courtesy manuals have much in common with jests of the period, and it is their similarities that help account for the prominent place jesting often assumes in the handbooks' treatments of oratory and courtly conduct. Like early modern jests, rhetoric and courtesy manuals must be seen as responses to geographic and, especially, social mobility, although the nature of each kind of manual's response differs considerably. The rhetorics were, in effect, handbooks on social mobility. They were typically written by would-be elites who aspired to rise above their lowly status and occupy positions of power and privilege. Rebhorn calls their authors "[m]en on the make" who, although baseborn, were driven by a fervent desire for social preferment (Rebhorn 1995: 16). Their social aspirations led many of these writers to incorporate into their treatises "fantasies" of social mobility and even social domination (Rebhorn 1995: 16). In his Arte of English Poesie (1988 [1589]), for instance, George Puttenham is very explicit about the perceived connection between oratorical skill and social advancement, for he promises to pull his reader "first from the carte to the schoole, and from thence to the Court, and ... [prefer] him to your Majesties service" (304), that is, from the geographic margins to its center, and from the bottom of the social scale to its top. ${ }^{7}$ Like the rhetorics, handbooks on courtly conduct were also written in response to widespread increases in social and geographic mobility. However, unlike the rhetorics, which, for the most part, tried to facilitate mobility, the courtesy manuals, at least initially, 
sought to suppress it. According to Whigham, the "corpus of Renaissance courtesy literature began to develop at a time when an exclusive sense of aristocratic identity ... was being stolen, or at least encroached upon, by a horde of young men not born to it" (Whigham 1984: 5). As part of their effort to repulse this "horde" of newcomers and upstarts, members of the elite composed handbooks on courtly conduct "in a gesture of exclusion," a gesture meant to reinforce and fortify boundaries between ruling and subject classes (Whigham 1984: 5). This seems to be precisely what Castiglione (1900 [1561]) has in mind when he has one of his interlocutors propose that he and the others discuss the ideal courtier in order to "disgrace therefore many untowardly asseheades, that through malepertness thinke to purchase them the name of good Courtyer" (41). ${ }^{8}$ Ironically, however, courtesy manuals were then "read, rewritten, and reemployed by mobile base readers to serve their own social aggressions" (Whigham 1984: 5). Once the modes of behavior and speech supposedly (and exclusively) characteristic of aristocratic identity had been made explicit and codified, they became available for imitation by gentry and baseborn alike. In this way, the early courtesy manuals undermined their own attempts to stifle the ambitions of this "mobile base" readership. Instead, they unwittingly fueled such ambitions.

The handbooks' preoccupation with social mobility, with the possibilities and threats of different kinds of people occupying the same social space, leads to an even more striking similarity between rhetoric and courtesy manuals and jests of the period. If early modern jests typically dramatize encounters between people of divergent social origins, then the near paradigmatic situation represented in the manuals has the same structure as a jest. Throughout these manuals, orators and courtiers are frequently, but not exclusively, portrayed communicating with people whose status is either above or beneath their own. The rhetorics often place orators in situations where they speak down to a baseborn populace, persuading them this way or that. Or they give accounts of orators addressing princes and kings, offering them counsel and advising them on important matters of state. These diverse communicative settings are summed up by Richard Rainolde in his Foundacion of Rhetorike (1969 [1563]) when he says orators "drawe unto theim the hartes of a multitude ... and speake before Princes and rulers" (Ai verso). Even in the more mundane world of the professional letter writer, or secretary, communication across social difference is the norm. In The English Secretary (1967 [1599]), an Elizabethan ars dictaminis, Angel Day advises 
his readers to consider "the reputation of the partie with whom we write" when composing a letter, for the secretary will have occasion to address a diversity of social types, and the form and content of the letter should be adapted accordingly:

[I]n one sort we frame them [letters] to old men, in another sort to young men, one way to sad and grave persons, another to light and young fellowes: one platforme to Courtiers' another to Philosophers. To great and notable personages, with a dutie speciall, appropriate to their calling: To our betters, always with submission: To our inferiors benignly and favourably ... (Day 1967 [1599]: 4).

This list of the range of rhetorical situations the secretary is likely to confront suggests the complexities of writing business letters in the period - how the secretary's discourse must embody not only the character but also the relative status of the person he addresses. Howver, this list also reads like a catalogue of potential "joking situations," as Thomas defines the term. A situation, for instance, in which a secretary addresses "great and notable personages" is structurally ambiguous. And although Day's prescription to address such people "with dutie speciall, appropriate to their calling" is intended to manage that ambiguity and lessen its impact, the situation is nevertheless fraught with incongruities that may be drawn upon or result in the production of jests.

Courtesy manuals are also concerned with communication across social boundaries. The title page of S. Robson's Court of Civile Courtesie (1591) announces the manual's primary aim: to teach "younge Gentlemen" how to "frame their behaviour according to their estates, at all times, and in all companies: Thereby to purchase worthy praise, of their inferiors: and estimation and credite among theyr betters." As the rest of the manual suggests, they will purchase this praise and estimation if they can shift effortlessly between two modes of interaction, "curtesy" and "curiositie": that is, between showing respect and deferring to their social betters, on the one hand; and maintaining a certain distance and standoffishness when in the company of their inferiors, on the other. The second book of Stefano Guazzo's Civile Conversation (1925 [1581]) is, in fact, all about communication between different kinds of people. Its argument promises to discuss:

first of the manner of conversation, meete for all persons, which shal come in any companie, out of their owne houses, and then the particular points, which ought to bee observed in companie betweene yong men, and old, gentlemen, and 
yomen, Princes and private persons, learned and unlearned, citizens, and straungers, religious, and secular, men, and women. (vol. 1: 109)

Again this reads like a catalogue of potential jesting situations. In fact, Guazzo makes extensive use of jests in this book to illustrate appropriate and inappropriate forms of interaction between the social types listed above. More generally, the prescriptions offered in this manual (and many of those offered in other handbooks of the period) are largely designed to help speakers handle the tensions and anxieties that arise when different kinds of people meet. And it is precisely these tensions and anxieties of which jests are made. For early modern writers of rhetoric and courtesy manuals, then, the jest offers a particularly rich and highly economical vehicle for modeling what the manuals posit as the near paradigmatic situation orators and courtiers are likely to face on a daily basis - that is, meetings between people of divergent social and geographic origins. In other words, the jests appearing in these manuals can be viewed as a collection of scripts or cautionary tales that orators and courtiers are to follow or avoid in their daily interaction with others. For the most part, these jests serve as reminders that speakers must preserve, in their every utterance, hierarchical relations already in place between themselves and other participants, even when those speakers are striving to rise above their ascribed status and secure positions among the social elite. The problem, of course, is that encounters between different kinds of people are primed for inversions and reversals of all sorts (between high and low, inside and out). And jesting, because it involves potentially volatile and chaotic energies, only serves to reinforce that instability.

\section{Socially conservative uses of jesting}

Near the beginning of his lengthy treatment of jesting in The Book of the Courtier, Castiglione broadly characterizes the rhetorical efficacy of jesting. According to Castiglione, this efficacy lies in the pleasure jesting affords an audience, a pleasure that all humans desire since, as he says, "the minde ... by nature is drawen to pleasantness and coveteth quietness and refreshing" (156). In exchange for this "pleasantness," the listeners give the speaker their "good will." Castiglione then extrapolates from these observations about the rhetorical dynamics of humor, places jesting within the larger category of recreation, and then delivers a quasihistorical account of the origins of recreation in general, suggesting that 
recreation, and hence jesting, is a means for maintaining social stability and preserving existing social relations. He says:

And because we beare good will to suche as are the occasion of this recreation of oures, the manner was emonge the kinges of old time, ... to get the good will of the people withall, and to feede the eyes and myndes of the multitude, to make great Theatres, and other publyque buildings, and there to showe new devices of pastimes, running of horses and Charettes, fightinges of men together, straunge beastes, Comedies, Tragidies, and daunses of Antique. Neither did grave Philosphers shonn these sightes, for manie tymes both in thys maner and at bankettes they refreshed their weerysome myndes, in those high discourses and divine imaginacions of theirs. The which in lykewyse all sortes of men are wyllinge to doe, for not onlye Plaughmen, Mariners, and all such as are inured wythe harde and boysterous exercises, with hande, but also holye religious men and prisoners that from hour to hour waite for death, goe about yet to seeke some remedy and medicine to refreshe themselves. Whatsoever therefore causeth laughter, the same maketh the minde jocunde and giveth pleasure, nor suffreth a man in that instant to minde the troublesome greefes that oure life is full of. (157)

Here recreation is characterized as a form of social control, a characterization that anticipates modern "safety-valve" theories used by sociologists and anthropologists to analyze the functions of ritual and festivity. ${ }^{9}$ According to these theories, designated periods of release from the constraints of everyday life are sanctioned because they allow subjects to blow off steam, so to speak, and vent frustrations towards the powers that be. Having vented these emotions in a safe way, the reasoning goes, these subjects are less likely to revolt in earnest.

Although proto-anthropological and sociological, Castiglione's passage characterizes the mechanisms of this form of social control in rhetorical terms, as a motivated gesture to secure a particular effect. The constructions of theaters and public buildings by the "kinges of old time" is motivated by a desire "to get the good will of the people withall, and to feed the eyes and myndes of the multitude." By doing so, the kings may secure the internal stability of their realms and perpetuate the power of their positions. And recreation seems a particularly effective means for achieving these ends because, according to Castiglione, it is desired by all levels of society and affects social types ranging from philosophers, clergymen, mariners and ploughmen, down to prisoners. Moreover, as Castiglione describes it, recreation has an almost narcotic effect; it is "medicine" that causes all people, while under its spell, to forget "in that instant ... the troublesome greefes that [their] life is full of." In effect, 
kings who supply recreation to their subjects are engaged in a rhetorical gesture writ large. In exchange for the "pleasantness" derived from recreation, they hope not only to win the good will of their subjects but also to secure their willing compliance.

In this account of the origins of recreation, Castiglione offers a description of the macro-dynamics of recreation (of which jesting is a species) and how it functions as a socially conservative force throughout an entire kingdom. However, we can also find many examples of Renaissance writers (Castiglione included) who focus on the particulars of a given humorous exchange. Implicit in many of their comments is a concern for preserving existing social relations. In his Garden of Eloquence (1954 [1593]), Henry Peacham includes several figures of speech that can be used for humorous purposes, and to all of these he assigns a socially conservative function: they are to be used to correct or rebuke deviant conduct. For instance, irony "pertaineth chiefly to reprove by derision" (36); the chief function of antiphrasis, a form of irony, is to "reprehend vice, and mock folly" (24), sarcasmus, another figure, is to be used to "represse proud folly and wicked insolencie" (38), and the primary use of mycterismus, which Peacham defines as a "privie kind of mocke," is to "represse pride, rebuke folly, and taunt vice" (39). Here Peacham uses moral categories to describe the functions of these figures, categories or attributes that are not necessarily specific to one's social status. However, when he comes to prescribe the limits of their use, he often translates these moral categories into social ones and insists that these figures be used only in ways that preserve the status quo. Antiphrasis is not "seemely to be used of all persons, in respect of breach of duty: it were unmeete for the sonne to say, wisely spoken father, for it were as much, as to call his father foole: and likewise for a servant in his anger to use this figure against his master" (25). Similarly, irony is not a "meete form of speech for every sort of person to use, especially of the inferior toward the superior, to whom by some reason he oweth dutie, for it is against the rule of modestie and good manners ... to deride his betters" (36). These figures are not a "meete form of speech for every sort of person to use" because the trajectory of their force is downwards: to "represse" is to "push down," to "deride" is to "laugh down" (deridere), to rebuke is to "cut down" (from the Old French buchier). Inferiors who jest at the expense of their superiors talk down to them and thus flout social relations that are already in place.

In his Arte of English Posie (1988 [1589]), George Puttenham discusses many of these same figures. And although he doesn't explicitly assign 
them socially conservative functions or insist that they be used in ways that preserve the respective status of speaker and listener, he does include examples in which superiors use them against their inferiors, examples which Peacham would probably deem appropriate or fitting because their trajectories are congruent with the social positions of the participants involved. The figure sarcasmus, or what Puttenham also calls the "Bitter taunt," occurs "when we deride with a certaine severitie" (200). As an example, Puttenham recounts the response of Henry VIII when "one of his privy chamber ... sued for Sir Anthony Rowse, a knight of Norfolke that his Majestie would be good unto him, for that he was an ill begger." Having heard the reason why the knight did not state his case in person, Henry said, "[I]f he be ashamed to beg, we are ashamed to give" (200). Presumably, the knight intended his disinclination to beg before the king to be interpreted as a show of humility. The gesture, however, is ambiguous. Begging is a form of supplication, a sign of deference, someone who is reluctant to beg, therefore, may be regarded as someone who is reluctant to defer. The king seizes upon this ambiguity and uses it against the knight or, at least, the person who speaks for him. In the process, the king asserts both his superiority and the inferiority of the supplicants, reminding the latter of their proper social place. Puttenham uses a similar anecdote to illustrate the figure of irony, or the "Drie mock." A soldier appeared before the king and "praid his reward, shewing how he had bene cut in the face at a certain battell fought in [the king's] service." The king quickly responded, "[Y]e may see ... what it is to runne away and looke backwards" (199). With his initial appeal to the king, the soldier tries to define the situation in such a way that his cut will be interpreted as a sign of courage meriting reward. But the appeal is also an indirect complaint against the king's failure to pay, and thus a form of criticism directed at the king. The king, however, turns the soldier's definition of the situation on its head and redefines the cut as a sign of cowardice, a failure to fight, and thus a fitting reward in and of itself. In both of these examples, the trajectories of the jests are congruent with the relative statuses of the participants. As such, they not only preserve existing social relations but also bring back in line those who threaten the system.

In both of these examples, jesting is used as a relatively mild rebuke, a way to check the behavior of those who inadvertently step out of line. However, the manuals also suggest that jesting can be used to put down people who pose a more serious challenge to the status quo. In his 


\section{C. Holcomb}

Art of Rhetoric (1994 [1560]), for instance, Thomas Wilson says that the poor and wretched are generally unsuitable targets of laughter, for "none can bear to have them mocked, but think rather they should be pitied." However, if they "foolishly vaunt themselves" and act in ways above their ascribed status, then they become fair game (166). Under such circumstances, a speaker is justified, even obligated, to take them down a notch. A similar, but more lengthy, passage can be found late in the second book of Guazzo's Civile Conversation where the author's two interlocutors discuss appropriate and inappropriate forms of interaction between gentlemen, on the one hand, and yeomen and others of inferior status, on the other. During this discussion, one of the interlocutors, Annibale Magnocavalli, raises the subject of upstarts and those who "will not acknowledge and confesse themselves inferior to Gentlemen" (vol. 1: 195). Annibale elaborates, saying there are many "common people" who "fall into such blinde arrogancie, and so foolish a vaine, that they will not sticke to vaunt themselves to be that which they are not, and both in their talk and their apparel brave it out like Gentlemen" (vol. 1: 195). The other interlocutor, the author's brother, shares his friend's concerns and cites instances of this social phenomenon in his native Italy where one doesn't have to look far to see "riche Peasaunts, who are not ashamed to attire themselves like Gentlemen, to wear weapons by their side, and such like ornaments, which are proper only to gentlemen" (vol. 1: 196). The problem with such behavior, as Guazzo sees it, is that it leads to interpretive confusion and the blurring of social boundaries: "And this abuse is so in use at this day ... [that] a man can discern no difference in estates" (vol. 1: 196). A tailor, for instance, accustomed "to weare weapons, and to be appareled like a Gentleman, is not knowne what he is, until he be seene sowing in his shop" (vol. 1: 196).

To guard against this "disorder and confusion," Guazzo recommends that Italy follow the practice of France and create and enforce sumptuary laws whereby "severall apparell is worne, according to everie ones calling" (vol. 1: 197). Annibale agrees and calls upon princes to "put their handes hereto, and cut the combs of these clownish cockscombes, and make them come down from their degree of gentrie, by forcing them to weare such apparel as may be at least different from Gentlemen" (vol. 1: 197). However, if legislation to "refourme that abuse" is not immediately forthcoming, Annibale says gentlemen still have a strategy for dealing with the situation themselves. And that strategy is laughter. He says, "[T]hose who are gentlmen indeed, ought not to be moved with the 
matter, but rather laugh at it" (vol. 1: 197). In other words, gentlemen should not appear ruffied at what both interlocutors admit is a very disturbing situation; instead, they should laugh it off as if it were not troubling, but simply ridiculous. Presumably the effect of their laughter would be to reestablish their social superiority.

Annibale and Guazzo actually adopt this strategy during this discussion and use derision when they speak of those who "brave it out like Gentlemen." As we have already seen, Annibale calls them "clownish cockscombes" and says that when they ape gentlemanly conduct, they act in "so foolish a vaine." He also refers to them as "malepert clownes" who by their presumption disgrace the "honour and degree of gentrie" (vol. 1: 197). Guazzo even cracks jests at their expense. He compares them to the "poore drudge brought in in the Comedie" who said that "his father was a goldsmith," but when asked what work his father did "belonging to that occupation," he responded that "hee set stones in morter" (vol. 1: 195). In another comparison, Guazzo says that an upstart is "like the mule who beeing demaunded of his birth, and beeing ashamed to say that he was an Asses sonne, answered, that he was a horses cousin" (vol. 1: 195-196). In all of these passages the objects of laughter are social inferiors who claim positions in status above those ascribed at birth. And the function of these derisive terms and jests is to define those claims as both false and ludicrous, and, more important, to preserve distinctions threatened by the supposedly presumptuous behavior of upwardly mobile merchants and tailors.

\section{Socially disruptive uses of jesting}

In his account of the origins of recreation, Castiglione sees jesting and, more generally, recreation as a way for the "kinges of old time" to gain the good will of their subjects and, in doing so, to secure the internal stability of their kingdoms. This account is remarkable not only because it assigns a socially conservative function to jesting but also because it suggests that jesting is somehow connected with political power - that it could serve as a means of rule. Castiglione is not alone in viewing jesting in this way. As we have seen, Puttenham offers examples of kings using humor not only to assert their own social superiority but also to put inferiors back in their proper social place. Guazzo even allows for laughter to stand in for a royal injunction regulating the apparel worn by 


\section{C. Holcomb}

subjects. Wilson (1994 [1560]) also sees a connection between jesting and political power. And although he doesn't offer examples of kings delivering jests, he does use images of rule to characterize the power of jesting. He says:

[T]he witty and learned have used [jesting] ... ever among their weighty causes, considering that not only good will is got thereby (for what is he that loveth not mirth?) but also men wonder at such a head, as hath men's hearts at his commandment, being able to make them merry when he lists. (166)

The possibilities for punning on the word "head" in the phrase "wonder at such a head" are tempting. In one sense it refers to the mind and intellect of the speaker; in another sense, though, it suggests the "head," or ruler, of the body politic, a ruler who commands "men's hearts" and instills in them a sense of "wonder."

But here's a crucial difference. Although Wilson uses images of rule to characterize the power of jesting, the people he says wield this power are not the "kinges of old time," that is, the legitimate rulers. Instead, Wilson calls them the "witty and learned," names which don't locate these men in terms of social status, but in terms of ability. In a sense, these names suggest a certain autonomy, a certain independence, from the constraints and restrictions of the existing hierarchy. For if the power of jesting is as great as Wilson says it is, then these "witty and learned" speakers could theoretically swagger into any situation, rifle off a few jests, and take control of their listeners irrespective of their own social rank or the ranks of the other participants involved. The difference, then, between Castiglione's account of the origins of recreation and the passages just quoted from Wilson is that in the latter the power of jesting is dislodged from its legitimate seat and placed in the hands of anyone with the readiness and ability to master the techniques of jesting that Wilson is about to offer.

The possibility of dislocating the power of jesting from legitimate users and using it against the system, while occasionally a source of enthusiasm for Wilson, was by and large a cause of much anxiety and a little confusion. Although the rhetoric and courtesy manuals view jesting as a potent resource for defending the status quo, they also recognize that jesting is not the sole property of those in positions of power - that is, those who have the most at stake in the existing system. Rather, jesting is a talent that any person may have regardless of social status or education. Wilson expresses what he regards as the popular opinion on this issue: "to have this gift 
[of jesting is] ... so easy that every varlet or common jester, is able to match with the best" (164). While such a view may be used to trivialize jesting by relegating it to that which is "common," the implication still is that a talent in jesting has a leveling effect and can place scoundrels and jesters on par with the "best." According to Guazzo, this talent may actually give inferiors the edge over their betters: "[there are] many men of greate wisdome and learning, who in pleasaunt matter have no grace at all, and contrariwise, many ignorant men, even of the common sorte, will handle a pleasaunt matter so finely, that they will make Heraclitus him selfe laugh at it" (vol. 1: 159). In other words, an able wit may allow the "common sort" to outshine their superiors, to steal the spotlight from them and capture the attention of the powerful.

In some instances, jesting may allow inferiors to get the better of their superiors in a battle of wits. As we saw with Peacham's warnings concerning the uses of irony, inferiors should never jest at the expense of their superiors. Some manuals advise speakers to avoid the reciprocal practice. That is, they recommend that superiors should guard against jesting with their inferiors, the risk being that if they are outmaneuvered by an inferior in a contest of wit they will suffer social degradation. In his Courte of Civile Courtesie (1591), Robson says, "I would not advise any man to jest mutch with his inferiors, unlesse they be such as he knoweth, both can and will use restraint of over malepartnes. For if a Gentleman should be saucily used by jest, by his inferiour, he cannot escape disgrace, whether he beare with it, or quarell for it" (12). According to Francis Bacon (1870 [1623]), the mere act of engaging an inferior in a battle of wits is enough to cause a speaker disgrace. He says that under no circumstances should a "wise man contend with a fool," for "it is no victory to conquer, and a great disgrace to be conquered" (vol. 5: 38). Once the wise man enters such a contest, once that threshold is crossed, degradation will inevitably be the result: "it makes no difference in this kind of contest, whether we take it in jest or in scorn and contempt, for, whichever way we turn, we must lose in dignity and can in no way quit ourselves well of it" (vol. 5: 38). Implicit in all of these passages is a particular logic of banter, a logic that seems analogous to the one that governs what Bourdieu (1972) calls the "game of honor." According to him, "To make someone a challenge is to credit him with the dignity of a man of honor, since the challenge, as such, requires a riposte and therefore is addressed to a man deemed capable of playing the game of honor, and of playing it well" (Bourdieu 1972: 11). A speaker who jests 
with his inferior - that is, engages him in banter - is implicitly offering him a challenge (can he match quip for quip?) and thus crediting him with a capacity to play the game of merriment. In doing so, however, he slights the social distance that should always obtain between superiors and inferiors by treating the inferior as a rival, an equal. More than that, he is making himself vulnerable to attack by his inferior. And should the inferior get the better of his superior, it seems that observers are more likely to register the superior's loss of face than the inferior's insolence.

Although Robson's and Bacon's admonitions are framed from the perspective of superiors and are offered as a strategy for protecting them against social degradation, they also imply a strategy by which inferiors can unleash their social aggressions. In other words, these admonitions indirectly suggest that inferiors can, in fact, use jesting against their superiors in order to degrade or embarrass them, especially when those superiors initiate the banter. Wilson rehearses a famous anecdote about the Emperor Augustus who met an unidentified man who was "like unto [Augustus] in countenance." Having observed the similarity in their looks, Augustus "asked him if ever his mother was in Rome, as though he had been his bastard. "The man replied, "No forsooth ... but my father hath been here very often." With this rejoinder, the "emperor was abashed, as though the emperor's own mother had been an evil woman of her body" (180). Here the man hoists Augustus with his own petard, so to speak, by turning Augustus's insinuation against him. Moreover, because the rejoinder works obliquely and allusively, the man can, if pushed in a corner, disown it, insist on a literal meaning, and say that all he meant was that his father had been to Rome often.

Guazzo offers a similar anecdote in which a servant, having first been mocked by his master, delivers a quip involving a verbal reversal which, in turn, suggests a reversal, if only temporarily, in the relational positions of the participants. One day when this master called his servant "King of fooles," the servant answered, "I would to God I were King of fooles, I would not doubt then, but I should beare rule over hym which is better than myself" (vol. 2: 103-104). By calling his servant "King of fooles," the master sought to ridicule him, to put him down. However, to be "King" implies ruling over - that is, being above - something or somebody. This ambiguity between putting down and elevating gives the servant an opening and allows him to define his master as his subject. Moreover, the rejoinder includes a bit of clever, and strategic, wordplay. The phrase "better than myself" suggests not only that the servant, as "King of 
fooles," will rule over his social "better" but also that he will rule over one who is "better" at being a fool. Also, the antecedent of "hym" is slightly ambiguous. If the servant had said, "beare rule over you," then the pronoun reference would have been definite: it would clearly refer to the master. By using "hym" instead, the servant creates a small degree of uncertainty in the pronoun's reference and thus gives himself a little room in which to maneuver should the master take him to task for his apparent insolence.

The preceding examples are instances in which inferiors ignore social relations in place prior to a joking exchange and jest at the expense of their superiors. There is, however, another way in which jesting may challenge or alter existing social relations. It may, as some manuals suggest either directly or indirectly, facilitate movement from a lower social position to a higher one, sometimes relieving the strain on the system in the process of transgressing it. In Castiglione's treatment of jesting, the author repeatedly warns his courtier to avoid all manners of jesting associated with the lower-class buffoon: a courtier should not jest "in suche wise as frantike, dronken, foolishe and fond men an in like maner commune jesters do" (158). Instead, he should only jest in ways that befit his elevated status and preserve the "astate of gentilman" (162). Castiglione goes on to differentiate between manners of jesting suitable to gentlemen and manners that smack of buffoonery, insisting that the courtier adopt the former and shun the latter. Behind these distinctions is a conservative intent: they seek to shore up boundaries between the nobility and the baseborn. However, by making these distinctions explicit - by detailing forms of jesting which display a gentlemanly status - Castiglione makes them available for imitation by would-be elites. Theoretically, the ambitious inferior would need only to learn, and put in practice, gentlemanly forms of jesting in order to make himself indistinguishable from other gentleman.

Wilson actually advances a subtle argument for the social advancement of his witty speaker. In contrast to Castiglione's witty courtier, who uses jesting to preserve and defend an already established identity - that of a gentleman - Wilson constructs an identity for the witty speaker that is in the process of becoming and that seeks official recognition and placement in a fixed social position. He says that a capacity to make others laugh "declares a quickness of wit worthy [of] commendation" (165). Also, the speaker who can gracefully deliver a humorous anecdote is "worthy to be highly esteemed" because "undoubtedly no man can do 
any such a thing except they have a great mother wit and by experience confirm such their comeliness" (173). Phrases such as "worthy [of] commendation" and "worthy to be highly esteemed" read like advertisements for the orator's ability. They also suggest that recognition is pending: although the witty speaker is worthy to be commended and esteemed, he has yet to be so. And what merits commendation, estimation, and - in short - preferment is not birth or title or physical strength, but intellect - that is, the "quickness of wit" the speaker displays in jesting. In other words, Wilson is positing a hierarchy of intellect, and although it runs dead against arguments advanced by the established gentry who (while trying to protect their ranks from "incursions from below") clung to the traditional notion of a hierarchy based on birth and landed wealth (Whigham 1984: 34), it allows Wilson to argue forcefully for the social advancement of his witty speaker, an advancement that would entail a transgression of the boundaries demarcating social status.

\section{Socially indeterminate uses of jesting}

In their theoretical statements about the practice of jesting, rhetoric and courtesy manuals, by and large, adhere to a binary logic when considering the social functions of jesting. A jest preserves the status quo by respecting existing social relations already in place prior to a joking exchange; or it challenges the status quo by ignoring, slighting, or flouting existing social relations. What this logic fails to account for, however, is the nature of jesting. A jest invariably combines and confuses incompatible elements, perspectives, or impulses in a single verbal form, a form in which they are paradoxically compatibly incompatible. In this way, a single jest may perform socially conservative functions and socially disruptive ones simultaneously.

Although the manuals never explicitly account for this property of jesting in their discussions of wit and humor, a few of them do hint at it in passages which call attention, however obliquely, to the indeterminacy of jesting. Late in the third book of The Civile Conversation (1925 [1574]), Guazzo's two interlocutors discuss how masters and their servants are to behave when together. At one point, the discussion turns to the question of whether or not servants who possess "imperfections," such as being rude, foolish, or insolent, ought to be tolerated or dismissed from their masters' services (vol. 2: 103). Annibale at first comes down 
on the side of dismissal, saying "I thinke suche servantes better lost then found, and the house the worse that they are in" (vol. 2: 103). But then he qualifies this statement and says that he knows "some honest gentlemen, who so long as their servantes are faythfull and trusty, care not though they be fooles, vaine talkers, or jesters to make them merry" (vol. 2: 103). Having said this, Annibale alters the initial question in two respects. First, the servants he mentions here are not just rude and insolent, they are also faithful and trusty, attributes which might be said to mitigate their other, less desirable qualities. Second, the phrase "to make them merry" suggests their masters take some degree of pleasure in their servants' jesting and fooling even when, Annibale goes on to say, their "mockes and scoffes" are directed at the masters themselves (vol. 2: 103). By re-framing the question in this way, Annibale far from settles the issue; in fact, he complicates it. That is, he opens up the possibility that the servants' unruly behavior simultaneously works against and reinforces the hierarchical relationship that should obtain between servants and masters. For by being unruly, these servants are serving their masters: they are making "them merry." And the masters, by giving off signs of delight even when they are the objects of derision, not only sanction such behavior but also give it further encouragement.

Although the two interlocutors do not come to this conclusion, their confusion over, and hesitancy to calculate the effect of, some forms of jesting implies they are on the brink of entertaining a more sophisticated model of jesting and the broader social functions jests might serve. Immediately after Annibale raises the issue of unruly servants and fails to resolve it, Guazzo chimes in with a jest that also fails to settle the issue, but does nevertheless illustrate its complexities:

There was a gentleman at Paris, who going foorth of hys Lodgyng, wylled hys servaunt to go to a Butcher named David, to buy him some tripes, but the Butcher having soulde all his tripes, hee retourned to his Mayster, who was at the Church hearing a sermon, and by chaunce as hee entered in at the Churche, the Preacher (meaning to alleadge some text of Scripture out of the Psalmes of David) sayde, what sayth David? Mary sayth he, that hee hath sold all his tripes. (vol. 2: 103)

After delivering this jest, Guazzo says, "Y know not whether that ought to be termed foolishnesse, or pleasantnesse." Guazzo's indecisiveness issues from an indeterminacy of the jest's social effects. The servant's answer to the preacher's rhetorical question is disruptive on several levels. It interrupts the preacher's sermon and disturbs the solemnity 
of the occasion. It also, whether wittingly or unwittingly, confuses King David, author of the Book of Psalms, with David, the local butcher, who sells tripe. Even the scene of the servant's answer contributes to its disruptiveness: it occurs, not behind the doors of the master's house, but in public - more than that, in church. As a consequence, not only does the servant run the risk of greater punishment, but he also may cause his master embarrassment. However, the servant's answer, as Annibale is almost willing to admit, is pleasurable. And perhaps that pleasure comes, not in spite of, but because of all the disruptions it causes.

Puttenham (1988 [1589]) rehearses an anecdote whose dynamics are similar to the butcher jest, but whose effects are more distinctly political. In his discussion of decorous speech, Puttenham tries to explain to his readers how "some skurrility and unshamefastness have now and then a certaine decencie ... by reason of some other circumstance." However, unable to articulate a "general rule" that would define which circumstances sanction scurrilous speech, Puttenham resorts to an example. Sir Andrew Flamock, "king Henry the eights standardbearer," was attending the king as he "entered the parke at Greenwich." The king blew his horn to announce his coming, and Flamock, "having his belly full, and his tayle at commaundement, gave out a rappe nothing faintly." The king, taken aback by the sound of Falmock's fart, said to him, "[H]ow now sirra?" And Flamock, "to exscuse his unmannerly act," responded, "If it please you Sir ... your Majesty blew one blast for the keeper and I another for his man." At this remark the king "laughed hartily and took it nothing offensively" (Puttenham 1988 [1589]: 274-275).

This anecdote contains two humorous acts: Flamock's fart and the witty excuse through which he apparently repairs the situation. The first act is socially disruptive, for it collapses several hierarchical oppositions. The king's mouth is equated with Flamock's behind, an equation that topples a cluster of other oppositions that are associated with the head and bottom: the mind and spirit versus the body and excrement, the sociopolitical head versus the socio-political bottom, the crown versus the commons. Also, the blowing of the king's horn is placed on the same level as breaking wind. Royal fanfares announce the coming of the king and, perhaps, are a symbol of his potency. Flamock's "rappe," by contrast, implies that what is coming is noxious and offensive and, perhaps, suggests that the king is nothing but a windbag. However, Flamock's witty response to the king's " $[\mathrm{H}]$ ow now sirra?" seems to repair the 
situation and re-establish some of the hierarchical distinctions leveled by the "rappe." He addresses the king as "Sir" and "your Majesty," both of which show that Flamock is acknowledging his inferior position relative to the king. Also, by saying that the "king blew one blast for the keeper and [Flamock] another for his man," Flamock uses the hierarchical relationship between these two men to mirror and reaffirm the one between the king and himself. Finally, Flamock's quick recovery redirects the trajectory of the "rappe" from targeting the king to targeting the keeper's man: it is aimed not up at the king, but down at a servant. Thus, it seems that Flamock successfully neutralizes his disruptive act, as the laughter of the king evidences. We could close the interpretation right here and say that Flamock's witty response contains and neutralizes the disruptive nature of his "unmannerly act." However, by doing so, we would fail to account for the mechanism of the jest itself. For if we think about it, the humor of this anecdote hinges on seeing Flamock's actions as simultaneously socially disruptive and socially conservative. Although Flamock's remark reinstates each participant in his proper social place, this anecdote also invites us to view the recuperative gesture as duplicitous. For, after he farts and then interprets his actions with his witty (and socially decorous) response, we are not likely to say, "Oh! That's what he meant by the fart. He meant it to be directed at the keeper's servant all along." It might be argued that the reader who comes up with such an interpretation doesn't get the jest. Rather, getting the jest requires the audience to "see that the meaning implicit in the punch line both follows from, and at the same time contrasts with or contradicts, the initial frame of reference" (Mulkay 1988: 31). The "initial frame of reference" in the Flamock jest would encourage reading Flamock's "rappe" as constituting a form of transgression. Such a reading is encouraged both by Puttenham's promise to offer "some skurrility and unshamefastness" and by the king's "How now sirra," a remark implying the king has also sensed that a transgression has occurred. Flamock's witty response, the punch line in this case, "follows from" this initial frame of reference in the sense that he is trying to make the best of a bad thing and "excuse his unmannerly act." However, it offers an interpretation of the "rappe" which contradicts our initial inferences about its transgressiveness. We don't abandon this initial inference and substitute Flamock's recuperative interpretation for it. Instead, we keep both contradictory interpretations in play in order to enjoy the pleasure of the jest. 


\section{Conclusion}

In their discussions of jesting, early modern rhetoric and courtesy manuals reveal a congruence between their characterizations of jesting and more general cultural anxieties over social and geographic mobility experienced in the period. For conservative writers like Castiglione, Guazzo, and Peacham, jesting is a powerful resource for stifling mobility, shoring up social boundaries, and putting people back in their supposedly proper place. As we have seen, however, their conservative prescriptions are unable to contain the disruptive energies of jesting. More broadly, the social conservatism that informs their manuals in general are unable to suppress the pressures of mobility. The views of Puttenham and Wilson, by contrast, are closer to those expressed by the bumpkin who was featured in the jest with which this essay began. Puttenham, who promises to pull his readers from the "carte ... to the Court," and Wilson, who advances an argument for the social mobility of his witty speaker, acknowledge (as did the bumpkin) the possibility of self-fashioning, of identity being the product of artifice. For these writers, the instability of jesting could be turned to a tactical advantage. For if a single jest can combine incompatible elements and impulses in a form in which they are compatibly incompatible, then it enacts verbally what these two writers (and presumably many of their readers) desired literally - that is, to transgress, yet preserve, the existing social order.

Texas A\&M University

\section{Notes}

Correspondence address: chrish@unix.tamu.edu

1. It has become almost axiomatic in modern studies of joking and laughter that humor issues from the perception of some form of incongruity. The incongruity theory of humor, as it is now commonly called, is usually attributed to Kant, although it is implicit in Cicero's discussion of wit when he says that jests "point out something unseemly in no unseemly fashion" (1942: 373). Regardless of its origins, the incongruity theory of humor is the basis of nearly all theories and analyses of humor offered by social scientists, philosophers, linguists, and literary critics. See, for instance, Arthur Koestler (1964: 35-36), Victor Raskin (1985: 81), Michael Mulkay (1988: 26-27), Neal R. Norrick (1993: 8-9), and James F. English (1994: 7-9).

2. My use of the masculine pronoun here and throughout this essay reflects the gender bias of early modern writers of rhetoric and courtesy manuals. For them, jesting - and oratory, for that matter - was almost exclusively perceived as a male prerogative. 
3. Mary Douglas's article on jest perception is one of the earliest, and most influential, studies of joking that posits a congruence between social ambiguity and comic ambiguity (1968: 361-376). Keith Thomas draws heavily upon Douglas in his study of laughter in Tudor and Stuart England (1977). Others have critiqued and further refined Douglas' model of joking (Mulkay 1988: 152, and English 1994: 7-9).

4. The rise in social and geographic mobility in the period has been amply documented. After Henry VIII's break with Rome and the dissolution of the monasteries, a tremendous amount of land (a chief index of social status) became available on the open market. This wide availability of land, taken together with a number of other factors (including demographic growth, increased commercial activity, expansion of educational and professional opportunities, and, later on, New World exploration and settlement) contributed to a dramatic rise in social mobility, both upwards and downwards. Some of these same factors also encouraged increases in geographic mobility. Demographic growth, enclosure of open-field villages, unemployment and underemployment, and low wages caused many people, primarily the poor, to relocate (oftentimes on a seasonal basis) on order to make a living. However, geographic mobility was not limited to the poor. The sons of commoners and gentry alike flocked to the Universities and Inns of Court with hopes of receiving an education that would prepare them for a career in religion, law, or politics. Even among the gentry there was considerable migration. Lured by the attractions of London and by pressing legal and business demands, many nobles took up seasonal or semi-permanent residences in the burgeoning metropolis. On these issues, see Stone (1965), Whigham (1984: 1-31), Beier (1985: 29-48), and Clark and Souden (1987).

5. Whigham (1984: 6-31) offers a thorough analysis of this tension between ascribed and achieved status and its impact on definitions of aristocratic identity during the reign of Elizabeth. Mullaney (1988) discusses the destabilizing effects of lower-class migrants in London: "Distinguishing citizen from noncitizen became a doubtful task as the displaced and marginal population of the country came to London in increasing numbers" (19). On the topic of self-fashioning in early modern England, see, of course, Greenblatt (1980).

6. The phrase "calculus of effects" is borrowed from English (1994: 17).

7. For all facsimile editions of early modern texts, I have modernized spellings. As the occasion demands, I have changed i's to j's, u's to v's, and v's to u's.

8. I'm treating Sir Thomas Hoby's (1900 [1561]) translation of Castiglione's (1528) Il libro del cortegiarto - and, later, George Pettie's (1925 [1581]) translation of Stefano Guazzo's (1574) La civile conversatione - as documents in English literary, social, and rhetorical history, since both works (especially Castiglione's) were so influential in early modern England.

9. See, for instance, Max Gluckman's (1964) and Victor Turner (1977). Both writers discuss ritual inversions in primitive cultures and argue that rituals which may appear to challenge the social order actually preserve it. Burke (1978), using these two anthropologists as his point of departure, examines the relevance of their theories to early modern Europe (199-204). He argues that the ritual inversions which were part of popular festivals may not always serve the status quo. In fact, he examines several historical instances when ritual inversions offered the occasion for social revolt.

\section{References}

Bacon, Francis

1870 The Works of Francis Bacon. Ed. James Spedding. 15 vols. New York: Garrett Press Inc. 
Beier, A. L.

1985

Masterless Men: The Vagrancy Problem in England, 1560-1640. London: Methuen.

Bourdieu, Pierre

1977 [1972] Outline of a Theory of Practice. Trans. Richard Nice. Cambridge: Cambridge University Press.

Burke, Peter

1978 Popular Culture in Early Modern Europe. London: Wildwood House Ltd.

Castiglione, Baldassare

1900 [1561] The Book of the Courtier. 1528. Trans. Sir Thomas Hoby. London: Tudor Translations.

Cicero

1942 De Oratore. Trans. E. W. Sutton and H. Rackham. 2 vols. Cambridge: Harvard University Press.

Clark, Peter and David Souden (eds.)

1987 Migration and Society in Early Modern England. Totowa: Barnes \& Noble Books.

Day, Angel

1967 [1599] The English Secretary. Introduction Robert O. Evans. Gainesville: Scholars' Facsimiles \& Reprints.

Douglas, Mary

1968 The social control of cognition: some factors in joke perception. Man 3, 361-376.

English, James F.

1994 Comic Transactions: Literature Humor, and the Politics of Community in Twentieth-Century Britain. Ithaca: Cornell University Press.

Fry, William F.

1963 Sweet Madness: A Study of Humor. Palo Alto: Pacific Books.

Gluckman, Max

1964 Custom and Conflict in Africa. New York: Barnes \& Noble, Inc.

Greenblatt, Stephen

1979 Renaissance Self-Fashioning: From More to Shakespeare. Chicago: The University of Chicago Press.

Guazzo, Stefano

1925 [1581] The Civile Conversation of M. Steeven Guazzo. 1574. Trans. George Pettie. London: Tudor Translations.

Koestler, Arthur

1965 The Act of Creation. London: Pan Books Limited.

Mangan, Michael

1996 A Preface to Shakespeare's Comedies. London: Longman.

Mullaney, Steven

1996 The Place of the Stage: License? Play? and Power in Renaissance England.

Chicago: The University of Chicago Press.

Mulkay, Michael

1988 On Humour: Its Nature and Place in Modern Society. Cambridge: Polity Press.

Norrick, Neal R.

1993 Conversational Joking: Humor in Everyday Talk. Bloomington: Indiana University Press. 
Peacham, Henry

1954 [1593] The Garden of Eloquence. Introduction. William G. Crane. Gainesville: Scholars' Facsimiles \& Reprints.

Puttenham, George

1988 [1589] The Arte of English Poesie. Introduction. Baxter Hathaway. Kent: Kent State University Press.

Rainolde, Richard

1969 [1563] The Foundacion of Rhetorike. New York: Da Capo Press.

Raskin, Victor

1985 Semantic Mechanisms of Humor (Synthese Language Library 24).

Dordrecht: D. Reidel.

Rebhorn, Wayne A.

1994 The Emperor of Men's Minds: Literature and the Renaissance Discourse of Rhetoric. Ithaca: Cornell University Press.

Robson, $\mathbf{S}$.

1591 The Court of Civile Courtesie. London.

Stone, Lawrence.

1966 The Crisis of the Aristocracy 1558-1641. Oxford: Clarendon Press.

Thomas, Keith

1977 The place of laughter in Tudor and Stuart England. Times Literary

Turner, Victor

Supplement 21 January, 77-81.

1977 The Ritual Process: Structure and Anti-Structure. Ithaca: Cornell University Press.

Whigham, Frank

1984 Ambition and Privilege: The Social Tropes of Elizabethan Courtesy Theory. Berkeley: University of California Press.

Wilson, Thomas

1995 [1560] The Art of Rhetoric. Ed. Peter E. Medine. University Park: The Pennsylvania State University Press.

Zall, P. M. (ed.)

1963 A Hundred Merry Tales and Other English Jestbooks of the Fifteenth and Sixteenth Centuries. Lincoln: University of Nebraska Press. 